Artikel Riset

DOI : 10.33751/jf.v10i1.1923
Fitofarmaka Jurnal Ilmiah Farmasi

Vol.10, No.1, Juni $2020: 42-53$

p-ISSN : 2087-9164 e-ISSN : 2622-755X

\title{
SKRINING TOKSISITAS AKUT BEBERAPA FRAKSI BUAH KARONDA (Carissa carandas L.) PADA EMBRIO ZEBRAFISH (Danio rerio)
}

\author{
Zaldy Rusli, Bina Lohita Sari, Sri Wardatun, Wildan Aristyo \\ Program Studi Farmasi FMIPA Universitas Pakuan Bogor \\ Email: zaldy.rusli@gmail.com
}

\begin{abstract}
ABSTRAK
Dalam pengembangan obat baru, perlu dilakukan penelitian untuk menentukan keamanan dan efek dari suatu tanaman obat. Buah karonda (Carissa carandas L.) adalah tanaman yang memiliki potensi sebagai obat anti-inflamasi. Penelitian ini bertujuan untuk menentukan toksisitas akut fraksi n-heksana, etil asetat, dan air buah karonda menggunakan model hewan uji embrio ikan zebra (Danio rerio). Pengujian toksisitas akut mengacu pada protokol OECD No. 236 tahun 2012 dan dilakukan pengamatan perubahan morfologi embrio ikan zebra yaitu tulang ekor, yolk sac dan pericardium. Hasil toksisitas fraksi n-heksana, etil asetat, dan air masing-masing menunjukkan nilai LC50 adalah 608,26 $\mu \mathrm{g} / \mathrm{mL} ; 571,78 \mu \mathrm{g} / \mathrm{mL}$; dan 546,69 $\mu \mathrm{g} / \mathrm{mL}$. Hasil pengamatan perubahan morfologi pada usia 96 hours post fertilization (hpf) pada ketiga fraksi menunjukkan kelainan perubahan pada tulang ekor, edema yolk sac dan pericardium. Kategori ketoksikan bahan uji termasuk kategori tidak toksik.
\end{abstract}

Kata kunci: Buah karonda, toksisitas akut, embrio ikan zebra

\section{ACUTE TOXICITY SCREENING OF Carissa carandas L. FRACTIONS IN THE EMBRYO OF ZEBRAFISH (Danio rerio)}

\begin{abstract}
Carissa carandas L. fruit is a plant which has potential as an anti-inflammatory drug. In the development of new drugs, it needs to determine the safety and effects of the medicinal plant. This research aims to determine the acute toxicity of n-hexane, ethyl acetate and water of Carissa carandas L fruit use zebrafish (Danio rerio) as animal model test. Acute toxicity test refers to the OECD protocol No. 236 year 2013 and morphological observation in zebrafish embryo were tail bone, yolk sac and pericardium. The result showed that $\mathrm{n}$-hexane, ethyl acetate and water fractions were LC50 values of $608,26 \mu \mathrm{g} / \mathrm{mL} ; 571,78 \mu \mathrm{g} / \mathrm{mL}$; dan $546,69 \mu \mathrm{g} / \mathrm{mL}$. The observation of morphological result at the age of 96 hours post fertilization (hpf) both extract and fractions showed tail bone abnormality, yolk sac and pericardium edema. The toxicity category of the material was practically non-toxic.
\end{abstract}

Keywords: Carissa carandas L. fruit, acute toxicity, zebrafish embryo 


\section{PENDAHULUAN}

Dalam pengembangan obat baru, salah satu syarat agar suatu bahan dapat digunakan sebagai obat adalah dengan melakukan uji toksisitas (Parasuraman, 2011). Uji toksisitas akut merupakan uji pendahuluan terhadap keamanan suatu bahan (Depkes RI, 1992). Uji toksisitas akut bertujuan untuk melihat efek toksik suatu senyawa yang terjadi dalam waktu yang singkat setelah pemberian pada dosis atau konsentrasi tertentu. Nilai LC50 merupakan parameter dalam uji toksisitas akut. Berdasarkan nilai $\mathrm{LC}_{50}$ diketahui suatu bahan bersifat sangat toksik atau tidak toksik (Gad, 2014). Uji toksisitas akut dapat dilakukan dengan menggunakan embrio ikan zebra.

Ikan zebra merupakan hewan coba yang digunakan sebagai model dalam pengembangan obat baru untuk penelitian embriotoksik dan teratogenik (Bulck, et al., 2011). Hasil uji toksisitas pada embrio ikan zebra telah terbukti memiliki korelasi positif dengan hasil uji toksisitas pada mamalia (Rubinstein, 2006). Hasil uji toksisitas dengan metode ikan zebra juga telah terbukti memiliki korelasi dengan daya sitotoksik senyawa antikanker sebagai pencarian kandidat obat antikanker. Metode ini dipercaya memiliki tingkat akurasi yang tinggi, mudah dikerjakan, lebih cepat dan murah (Yang et al., 2018).

Buah karonda (Carissa carandas L.) adalah salah satu jenis tanaman obat yang memiliki aktivitas biologi sebagai antiinflamasi (Anupama et al., 2014). Tanaman ini mengandung senyawa bioaktif utama yaitu alkaloid, flavonoid, saponin, glikosida jantung, triterpenoid, fenolik dan tanin (Sudjaroen \& Suwannahong, 2017). Anupama et al. (2014) melaporkan bahwa ekstrak metanol buah kering karonda memberikan aktivitas antiinflamasi pada tikus Sprague Dawley dengan dosis 400 $\mathrm{mg} / \mathrm{kg} \quad \mathrm{BB}$ (Berat Badan) dengan penghambatan maksimum sebesar 76,12\%. Dhodi et al. (2015) juga melaporkan bahwa ekstrak buah karonda dapat memperbaiki kerusakan fungsi ginjal tikus Sprague Dawley dengan mekanisme stresss oksidatif. Kandungan fenolik total pada ekstrak etanol buah karonda memberikan efek antioksidan dengan IC50 sebesar 195,81 $\mu \mathrm{g} / \mathrm{ml}$ untuk DPPH dan 219,92 $\mu \mathrm{g} / \mathrm{ml}$ untuk nitric oxide (Mishra et al., 2017).

Berdasarkan uraian tersebut, perlu dilakukan uji toksisitas terhadap ekstrak dan fraksi-fraksi buah karonda menggunakan embrio ikan zebra guna mengetahui keamanan bahan uji. Uji toksisitas dilakukan terhadap fraksi nheksana, etil asetat dan air.

\section{METODE PENELITIAN}

\section{Alat}

Alat yang digunakan pada proses uji toksisitas adalah alat pembuat juice, vacuum dryer, well plate, akuarium, aerator, peralatan gelas dan mikroskop trinokuler.

\section{Bahan}

Bahan yang digunakan daging buah karonda yang sudah masak ditandai dengan warna merah tua, air sumur, pelarut n-heksana, etil asetat, aquadest, dimetil sulfoxide (DMSO), embrio ikan zebra.

\section{Cara Kerja}

\section{Determinasi}

Pada penelitian ini dilakukan determinasi tanaman buah karonda yang digunakan sebagai bahan baku untuk memastikan bahwa bahan baku yang digunakan merupakan bahan baku yang benar dan seragam. Determinasi buah karonda tanaman dilakukan di Lembaga 
Ilmu Pengetahuan Indonesia (LIPI), di komplek CSC-LIPI Jl. Raya Bogor Km.46, Cibinong, Bogor, Jawa Barat, Indonesia.

\section{Pembuatan Ekstrak Kering Fraksi Buah Karonda}

Bahan baku buah karonda sebanyak $8 \quad \mathrm{~kg}$ yang sudah masak diperoleh dari Taman Buah Mekarsari Jl. Raya Cileungsi-Jonggol Km.3, Mekarsari, Cileungsi, Bogor, Jawa Barat, Indonesia. Pembuatan ekstrak buah karonda dimulai dengan proses sortasi basah, pencucian, penyarian dan pengeringan. Buah karonda di sortasi basah untuk memisahkan cemaran dan ukuran agar seragam. Kemudian buah karonda dicuci dengan air mengalir sampai bersih untuk menghilangkan kotoran yang menempel. Setelah itu bahan baku dikeringkan dengan cara di angin-angin untuk menghilangkan air yang masih menempel setelah pencucian. Kemudian buah dipotong menjadi dua menggunakan pisau untuk membuang bijinya. Buah yang bijinya sudah dibuang dimasukkan ke alat juicer, kemudian dimasukkan ke wadah yang ditutupi oleh alumunium foil. Jus buah karonda dikeringkan menggunakan alat vaccum dryer hingga terbentuk ekstrak kering. Ekstrak kering dimasukkan ke dalam pot selai kaca dan disimpan dalam kondisi yang kering tidak terkena langsung dengan cahaya matahari. Rendemen ekstrak dihitung dengan membandingkan antara bobot awal dengan bobot akhir yang diperoleh dengan rumus sebagai berikut:

Rendemen $=\frac{\text { Bobot sari yang diperoleh }}{\text { Bobot awal }} \times 100 \%$

\section{Penetapan Kadar Air}

Penetapan kadar air ekstrak kering buah karonda dilakukan dengan metode gravimetri. Cawan uap ditara terlebih dahulu di dalam oven selama 15 menit. Kemudian serbuk simplisia dan ekstrak kental ditimbang masing-masing $2 \mathrm{~g}$ dalam cawan uap yang telah ditara. Selanjutnya serbuk dan ekstrak kental dikeringkan didalam oven pada suhu $105^{\circ} \mathrm{C}$ selama 5 jam. Simplisia ditimbang kemudian dikeringkan kembali didalam oven selama 1 jam. Dilakukan pengulangan kembali sampai bobot konstan atau sampai perbedaan bobot antara 2 penimbangan terakhir tidak lebih dari 0,25\% dan kadar air simplisia tidak boleh lebih dari 10\% (Kemenkes RI, 2011). Perhitungan kadar air dilakukan dengan persamaan dibawah ini:

Bobot basah = Bobot cawan + isi $(g)-$ bobot cawan kosong (g) sebelum pengeringan

Bobot kering = Bobot cawan + isi $(\mathrm{g})-$ bobot cawan kosong (g) setelah pengeringan

Kadar air $=\frac{\text { Bobot basah }(\mathrm{g})-\text { Bobot kering }(\mathrm{g})}{\text { Bobot sampel }(\mathrm{g})} \times 100 \%$

\section{Penetapan Kadar Abu}

Penetapan kadar abu ekstrak kering buah karonda dilakukan dengan menggunakan tanur. Krus ditara terlebih dahulu didalam tanur selama 15 menit pada suhu $800^{\circ} \mathrm{C}$. Kemudian ditimbang seksama 2 g sampel dan dimasukkan ke dalam krus silikat yang telah dipijar dan ditara. Krus yang berisi sampel dipijarkan di dalam tanur pada suhu $800^{\circ} \mathrm{C}$ sampai menjadi abu. Krus dikeluarkan dengan alat penjepit besi, didinginkan pada suhu kamar kemudian ditimbang hingga bobot tetap atau hingga perbedaan bobot antara 2 penimbangan terakhir tidak lebih dari $0,5 \mathrm{mg}$ tiap gram zat yang digunakan (Kemenkes RI, 2011). Kadar abu selanjutnya dihitung dengan persamaan berikut:

Kadar $\mathrm{abu}=\frac{(\text { Bobot krus }+ \text { abu simplisia })(\mathrm{g})-\text { bobot krus }(\mathrm{g})}{\text { Bobot sampel }(\mathrm{g})} \times 100 \%$ 


\section{Fraksinasi}

Fraksinasi ekstrak buah karonda dilakukan dengan metode ekstraksi caircair (ECC) menggunakan pelarut nheksana, etil asetat, dan air. Sebanyak $50 \mathrm{~g}$ ekstrak buah karonda dilarutkan dalam air hingga $100 \mathrm{~mL}$. Kemudian ekstrak tersebut ditambahkan $100 \mathrm{~mL}$ pelarut n-heksana dalam corong pisah. Kemudian dilakukan proses ekstraksi dengan pengocokan selama 15 menit hingga terbentuk 2 lapisan. Didiamkan terlebih dahulu agar terjadi pemisahan yang sempurna. Setelah itu dipisahkan fase-fase yang terbentuk ke wadah yang berbeda dan dilakukan 3x pengulangan. Kemudian fraksinasi dilakukan dengan etil asetat dengan cara yang sama dengan n-heksana. Sehingga diperoleh fraksi air, fraksi n-heksana, dan fraksi etil asetat. Fraksi tersebut diuapkan dengan menggunakan rotary evaporator.

\section{Analisis Fitokimia Ekstrak dan Fraksi}

Analisis fitokimia secara kualitatif dilakukan untuk mengetahui kandungan senyawa kimia dan golongan senyawa yang terdapat pada suatu tumbuhan bahan alam. Pada umumnya cara ini digunakan untuk mengetahui golongan senyawa tanin, flavonoid, alkaloid dan saponin.

\section{Identifikasi Tanin}

Ditimbang ekstrak sebanyak $2 \mathrm{~g}$ diekstraksi dengan etanol $80 \%$ sebanyak $30 \mathrm{~mL}$ dan dilakukan pengocokan selama 15 menit. Kemudian ekstrak disaring. Filtrat yang didapat diuapkan di atas penangas air. Filtrat yang telah diuapkan ditambah dengan larutan $10 \%$ gelatin, $\mathrm{NaCl}$ gelatin (laurtan $1 \%$ gelatin dalam larutan $10 \% \mathrm{NaCl}$ dengan perbandingan 1:1), dan larutan $3 \% \mathrm{FeCl}_{3}$. Tanin positif ditandai dengan terbentuknya warna endapan putih pada penambahan $10 \%$ gelatin, $\mathrm{NaCl}$ gelatin dan warna hijau biru hingga kehitaman pada penambahan $3 \%$ $\mathrm{FeCl}_{3}$ (Hanani, 2015).

\section{Identifikasi Flavonoid}

Ditimbang ekstrak sebanyak $0,5 \mathrm{~g}$ dilarutkan dalam $5 \mathrm{~mL}$ etanol $95 \%$. Larutan sampel diambil sebanyak $2 \mathrm{~mL}$. Kemudian ditambahkan dengan serbuk $\mathrm{Mg}$ sebanyak 0,1 g, dan ditambahkan dengan $\mathrm{HCl} 5 \mathrm{M}$ sebanyak 10 tetes dari sisi tabung dan lakukan pengocokan perlahan-lahan. Flavonoid positif ditandai dengan terbentuknya warna merah atau jingga. Jika terbentuk warna kuning jingga menunjukkan adanya flavon, kalkon, dan auron (Hanani, 2015).

\section{Identifikasi Alkaloid}

Ditimbang ekstrak sebanyak $1 \mathrm{~g}$ dikocok dengan $20 \mathrm{~mL}$ metanol dan $3 \mathrm{~mL}$ amonia. Dipanaskan pada suhu $60^{\circ} \mathrm{C}$ sambil dilakukan pengocokan selama 15 menit. Kemudian disaring, filtrat yang diperoleh diuapkan hingga volume kurang lebih $3 \mathrm{~mL}$, kemudian ditambah dengan $5 \mathrm{~mL} \mathrm{HCl} \mathrm{1N}$. Larutan diteteskan pada 2 kaca arloji masing-masing 3 tetes dan ditambahkan pereaksi alkaloid yaitu Dragendroff, Mayer, Bouchardat. Alkaloid positif jika terbentuk warna endapan coklat pada penambahan pereaksi Dragendroff dan Bouchardat dan terbentuk warna endapan putih pada penambahan pereaksi Mayer (Hanani, 2015).

\section{Identifikasi Saponin}

Ditimbang ekstrak sebanyak 0,5 g. Kemudian dikocok dengan $10 \mathrm{~mL}$ air. Saponin positif ditunjukkan dengan terbentuknya busa yang stabil dengan penambahan asam klorida. Busa tidak hilang selama beberapa menit (Hanani, 2015). 
Pengujian Toksisitas Buah Karonda pada Embrio Ikan zebra

Penyiapan Embrio Ikan Zebra

Embrio ikan zebra diperoleh dari peternak ikan lokal di Jl. Raya JakartaBogor No.10, Nanggewer Mekar, Cibinong, Bogor, Jawa Barat, Indonesia. Embrio yang diperoleh merupakan embrio yang telah di fertilisasi.

\section{Pengenceran Larutan Uji Toksisitas}

Larutan induk dibuat pada konsentrasi $1000 \mu \mathrm{g} / \mathrm{mL}$ dengan cara menimbang $100 \mathrm{mg}$ ekstrak dan dilarutkan menggunakan air sumur sampai tanda batas $100 \mathrm{~mL}$. Kemudian larutan induk dibuat pengenceran pada konsentrasi 50, 250, 500, 750, dan 1000 $\mu \mathrm{g} / \mathrm{mL}$ dengan persamaan $\mathrm{V} 1 \mathrm{~N} 1=\mathrm{V} 2 \mathrm{~N} 2$. Kelima deret konsentrasi hasil pengenceran tersebut digunakan untuk penentuan konsentrasi letal. Setelah diperoleh konsentrasi letal maka dibuat deret konsentrasi yang lebih spesifik terhadap $\mathrm{LC}_{50}$ yaitu pada konsentrasi 500, 550, 600, 650 dan $700 \mu \mathrm{g} / \mathrm{mL}$. Dibuat larutan induk untuk pengujian toksisitas ekstrak dan fraksi yaitu $700 \mu \mathrm{g} / \mathrm{mL}$ dengan cara menimbang $70 \mathrm{mg}$ ekstrak kering buah karonda dan dilarutkan menggunakan air sumur sampai tanda batas $100 \mathrm{~mL}$. Kemudian dibuat pengenceran dari larutan induk 700 $\mu \mathrm{g} / \mathrm{mL}$ menjadi $500,550,600$ dan 650 $\mu \mathrm{g} / \mathrm{mL}$.

\section{Penyeleksian Embrio}

Embrio ikan zebra yang digunakan pada penelitian ini adalah embrio yang berusia 8 jam. Sebelum embrio dimasukkan ke dalam masingmasing well plate uji embrio harus diseleksi terlebih dahulu. Dipilih embrio normal yang ditandai dengan adanya kuning telur. Embrio yang normal umumnya ditandai dengan warna yang bening. Dan embrio yang mati umumnya ditandai dengan warna putih susu (OECD, 2012).

\section{Uji Toksisitas}

Uji toksisitas pada embrio ikan zebra mengacu pada OECD No.236 tahun 2012 perihal pengujian toksisitas akut pada embrio ikan zebra. Dilakukan untuk mengetahui efek toksik ekstrak dan fraksi pada buah karonda melalui pengamatan daya tetas setelah diberikan paparan larutan uji selama 96 jam dan untuk mendapatkan nilai LC50 dari ekstrak dan fraksi-fraksi buah karonda.

Embrio ikan zebra yang berumur 8 jam pada tahap organogenesis, dipapar zat uji untuk jangka waktu 96 jam. Sebelumnya Embrio ikan zebra dimasukkan ke well plate yang mengandung larutan uji dengan menggunakan pipet mikro. Setiap well plate dimasukkan dengan 10 embrio, lalu pada masing-masing well plate ditambahkan deret larutan uji dengan 3 kali pengulangan. Embrio diinkubasi pada suhu kamar (El-Sayed Ali \& Legler, 2011). Pengamatan dilakukan pada jam ke-24, 48, 72 dan 96. Dalam pengamatan tersebut akan diperoleh empat data pengamatan yang dicatat sebagai indikator mematikan: (i) perubahan pada tulang belakang (ii) kelainan tulang ekor (iii) kelainan kuning telur (yolksac) dan (iv) edema perikardium. Toksisitas akut ditentukan berdasarkan salah satu hasil positif dari empat pengamatan tersebut dan dihitung sebagai nilai LC50.

\section{Analisis Data}

Embrio yang mengalami kematian pada jam ke-24, 48, 72 dan 96 dicatat sebagai data pengamatan. Data kematian yang diperoleh tersebut digunakan untuk menentukan nilai LC50. Nilai LC50 dihitung dengan menggunakan IBM 
SPSS versi 24.0 dengan metode grafik probit.

Data nilai LC50 yang diperoleh selanjutnya dianalisis dengan ANOVA (Analysis of Variance) menggunakan pola Faktorial Rancangan Acak Kelompok (FRAK) antara faktor larutan yang terdiri dari 4 tingkat (ekstrak sari, fraksi n-heksana, fraksi etil asetat dan fraksi air) dan factor waktu yang terdiri dari 4 tingkat (jam ke-24, 48, 72 dan 96) serta interaksi larutan dan waktu terhadap nilai LC50, selang kepercayaan 95\%. Hasil analisis ANOVA yang memberikan hasil berbeda nyata dianalisis lebih lanjut dengan uji lanjut metode Duncan. Analisis data ANOVA dan uji lanjut Duncan diproses dengan menggunakan program IBM SPSS Statistics 24 for Windows.

\section{Uji Toksisitas Ekstrak terhadap Daya Tetas Embrio Ikan Zebra}

Embrio ikan zebra yang berusia 8 jam dipapar dengan menggunakan ekstrak serta fraksi-fraksi buah karonda. Daya tetas embrio ikan zebra diamati pada kelompok kontrol negatif (perlakuan tanpa larutan uji toksisitas) dan kelompok dosis LC50. Daya tetas dihitung menggunakan rumus daya tetas dari Huang et al. (2018).

Daya tetas $=\frac{\text { Jumlah embrio yang menetas pada jam ke- } 96}{\text { Jumlah embrio pada awal pengamatan }} \times 100 \%$

\section{Uji Toksisitas Ekstrak terhadap Malformasi Embrio Ikan Zebra}

Malformasi embrio ikan zebra yang telah dipapar oleh bahan uji diamati. Pengamatan dilakukan pada kelompok kontrol negatif (K0), kelompok dosis 500 $\mu \mathrm{g} / \mathrm{mL}$ (P1), $550 \mu \mathrm{g} / \mathrm{mL}$ (P2), $600 \mu \mathrm{g} / \mathrm{mL}$ (P3), $650 \mu \mathrm{g} / \mathrm{mL}$ (P4) dan $700 \mu \mathrm{g} / \mathrm{mL}$ (P5) dengan periode waktu 24, 48, 72 dan 96 jam. Pengamatan malformasi dilakukan dengan menggunakan mikroskop trinokuler.

\section{HASIL DAN PEMBAHASAN Determinasi Tanaman}

Hasil determinasi menunjukkan bahwa bahan yang digunakan merupakan buah karonda dengan nama latin Carissa carandas Linn. dari suku Apocynaceae.

\section{Hasil Pembuatan Ekstrak Kering Buah \\ Karonda}

Rendemen yang dihasilkan dari ekstrak kering buah karonda sebesar 5,86\% . Hasil rendemen ekstrak yang diperoleh berbeda dengan hasil uji sebelumnya yang telah dilakukan oleh Mishra et al. (2017) yaitu didapatkan rendemen ekstrak kering buah karonda sebesar 2,0\%. Perbedaan hasil ini dapat disebabkan karena perbedaan waktu panen, suhu tumbuh, metode ekstraksi dan pelarut yang digunakan. Hasil uji organoleptik ekstrak, didapat ekstrak kering dengan aromatik khas kuat, rasa asam dan memiliki warna merah keunguan. Hasil ini sesuai dengan hasil yang telah dilakukan oleh Mishra et al. (2017).

\section{Hasil Kadar Air Ekstrak Kering Buah Karonda}

Penetapan kadar air merupakan salah satu parameter standarisasi suatu ekstrak untuk menentukan jumlah air yang terkandung dalam ekstrak. Adanya air dalam ekstrak akan mempengaruhi daya tahan ekstrak selama proses penyimpanan, karena air dapat menjadi media pertumbuhan mikroorganisme yang baik sehingga dapat menyebabkan perubahan senyawa kimia dalam ekstrak. Hasil yang diperoleh dari penetapan kadar air yaitu 2,83\%. Hasil ini sudah memenuhi persyaratan dimana syarat kadar air ekstrak tidak lebih dari 10\% (Kemenkes RI, 2011). 
Hasil Kadar Abu Ekstrak Kering Buah Karonda

Penetapan kadar abu merupakan proses pemanasan bahan uji pada temperatur tinggi dimana senyawa organik akan terdestruksi, sehingga hanya terdapat unsur mineral dan anorganik yang tertinggal. Hasil yang diperoleh dari penetapan kadar abu yaitu sebesar $4,478 \%$. Selain itu menurut penelitian Kumar et al. (2017) kadar abu ekstrak buah karonda diperoleh sebesar $12 \%$.

\section{Hasil Fraksinasi Ekstrak Kering Buah Karonda}

Fraksinasi bertujuan untuk memisahkan golongan utama senyawa kimia dari kandungan senyawa lain. Senyawa kimia yang bersifat non polar akan terdistribusi masuk ke dalam pelarut non polar sedangkan senyawa kimia polar akan masuk ke dalam pelarut polar. Berdasarkan nilai rendemen hasil fraksinasi diperoleh bahwa nilai rendemen terbesar adalah fraksi air yaitu sebesar 65,04\%, lalu fraksi etil asetat yaitu sebesar $10,41 \%$ dan fraksi nheksana memiliki nilai rendemen terkecil yaitu sebesar 5,99\%. Nilai rendemen tersebut menunjukkan bahwa sebagian besar senyawa yang terdapat dalam buah karonda adalah senyawa polar. Hal ini sesuai dengan hasil penelitian Azeez et al. (2016) yang menyebutkan bahwa sebagian besar kandungan senyawa aktif yang terdapat pada buah karoda adalah golongan flavonoid dan asam fenolik. Golongan tersebut dapat larut dalam pelarut polar seperti air (Harborne et al., 2006).

\section{Hasil Uji Fitokimia Ekstrak dan Fraksi Buah Karonda}

Pengujian fitokimia merupakan suatu metode kimia yang digunakan untuk mengetahui senyawa metabolit sekunder yang terkadung dalam suatu ekstrak maupun fraksi. Hasil uji fitokimia ekstrak dan fraksi buah karonda dapat dilihat pada Tabel 1 .

Tabel 1. Hasil Uji Fitokimia Ekstrak dan Fraksi Buah Karonda

\begin{tabular}{|c|c|c|c|c|}
\hline \multirow[b]{2}{*}{ Parameter Uji } & \multicolumn{3}{|c|}{ Hasil Uji Fitokimia } & \multirow[t]{2}{*}{ Keterangan } \\
\hline & $\begin{array}{l}\text { Fraksi } \\
\text { Heksana }\end{array}$ & $\begin{array}{l}\text { Fraksi Etil } \\
\text { Asetat }\end{array}$ & $\begin{array}{l}\text { Fraksi } \\
\text { Air }\end{array}$ & \\
\hline \multirow{2}{*}{ Tanin } & + & + & + & $\begin{array}{l}\text { Gelatin: Endapan } \\
\text { Putih }\end{array}$ \\
\hline & + & + & + & $\begin{array}{l}\mathrm{FeCl}_{3}: \text { Hitam } \\
\text { kehijauan }\end{array}$ \\
\hline \multirow[t]{2}{*}{ Flavonoid } & - & + & + & $\begin{array}{l}\text { Zn: Merah } \\
\text { lembayung }\end{array}$ \\
\hline & - & + & + & Mg: Jingga \\
\hline \multirow{2}{*}{ Alkaloid } & + & + & - & $\begin{array}{l}\text { Pereaksi Dragendorf: } \\
\text { Endapan Orange }\end{array}$ \\
\hline & + & + & - & $\begin{array}{l}\text { Pereaksi Bouchardat: } \\
\text { Endapan Coklat }\end{array}$ \\
\hline Saponin & + & + & + & $\begin{array}{l}\text { Terbentuk buih stabil } \\
2,5 \mathrm{~cm}\end{array}$ \\
\hline
\end{tabular}

Analisis uji fitokimia pada ekstrak buah karonda menunjukkan hasil yang sesuai dengan penelitian yang dilakukan oleh Virmani et al., (2017) yang menyatakan buah karonda mengandung flavonoid, alkaloid, saponin dan tanin. 
Sedangkan hasil uji fitokimia pada fraksi menunjukkan hasil yang sesuai dengan penelitian yang dilakukan oleh Rohmah et al., (2019) yang menyatakan fraksi nheksana mengandung tanin, alkaloid dan saponin, fraksi etil asetat mengandung tanin, flavonoid, alkaloid dan saponin, fraksi air mengandung tanin, flavonoid dan saponin.

Diduga flavonoid yang terkandung dalam buah karonda tergolong kedalam flavonoid glikosida yang bersifat mudah larut dalam pelarut polar seperti metanol, etanol, butanol dan etil asetat sehingga memberikan hasil negatif pada fraksi n-heksana. Alkaloid bersifat basa dan cenderung larut dalam pelarut non polar (Hanani, 2015), sehingga memberikan hasil yang negatif pada fraksi air.

\section{Hasil Uji Ekstrak dan Fraksi terhadap Nilai $\mathbf{L C}_{\mathbf{5 0}}$}

Hasil uji toksisitas akut dengan metode Zebra Fish Embryo Acute Toxicity (ZFET) menunjukkan semakin lama periode paparan ekstrak dan fraksi maka semakin meningkat angka kematian terhadap embrio dan dengan meningkatnya angka kematian sampai akhir paparan maka LC50 semakin rendah.

Hasil analisis data menggunakan probit pada periode waktu 96 jam menunjukkan bahwa rata-rata fraksi air menghasilkan nilai LC50 terkecil diikuti dengan fraksi etil asetat, dan fraksi nheksana (Tabel 2). Semakin kecil nilai LC50 maka semakin toksik. Kategori toksisitas bahan uji berdasarkan nilai LC50 dari US Fish and Wildlife Service pada table 3 (Waynon \& Finley, 1980) semuanya termasuk kategori tidak toksik yaitu berada pada rentang 100-1000 $\mu \mathrm{g} / \mathrm{mL}$.

Tabel 2. Nilai LC $_{50}$ Ekstrak dan Fraksi Buah Karonda $(\mu \mathrm{g} / \mathrm{mL})$

\begin{tabular}{clccc}
\hline Waktu & Fraksi n-heksana & $\begin{array}{c}\text { Fraksi etil } \\
\text { asetat }\end{array}$ & Ekstrak air & Rata-rata \\
\hline 24 jam & $685,58 \pm 11,878$ & $596,40 \pm 5,89$ & $633,09 \pm 6,66$ & $636,511^{\mathrm{a}}$ \\
48 jam & $630,13 \pm 15,34$ & $599,04 \pm 13,38$ & $610,66 \pm 0,30$ & $613,779^{\mathrm{b}}$ \\
72 jam & $617,18 \pm 12,90$ & $588,17 \pm 9,64$ & $603,57 \pm 8,22$ & $603,030^{\mathrm{c}}$ \\
96 jam & $608,26 \pm 10,40$ & $571,78 \pm 18,82$ & $546,69 \pm 3,03$ & $577,020^{\mathrm{d}}$ \\
\hline
\end{tabular}

Tabel 3. Skala Toksisitas Akut Berdasarkan Fish and Wildlife Service

\begin{tabular}{cc}
\hline Tingkat toksisitas & LC50-96 jam $(\mu \mathrm{g} / \mathrm{mL})$ \\
\hline Super toxic & $0,01-0,1$ \\
Highly toxic & $0,1-1$ \\
Moderately toxic & $1-10$ \\
Slightly toxic & $10-100$ \\
Practically non- toxic & $100-1000$ \\
Relatively harmless & $>1000$ \\
\hline
\end{tabular}

Hasil analisis data statistik menunjukkan adanya perbedaan pengaruh yang nyata $(\mathrm{p} \leq 0,05)$ antara faktor larutan, waktu serta interaksi larutan dan waktu terhadap nilai LC50, sehingga dilakukan uji lanjut duncan. Hasil uji lanjut duncan menunjukkan pelarut etil asetat dan air memiliki pengaruh yang sama terhadap nilai LC50. Pelarut air dan ekstrak sari juga menunjukkan pengaruh 
yang sama terhadap nilai LC50. Sedangkan ekstrak sari dan n-heksana memiliki pengaruh yang berbeda. Hal ini menunjukkan bahwa senyawa polar dan semi polar memiliki aktivitas yang baik dibandingkan senyawa non polar. Diduga aktivitas yang dihasilkan disebabkan kandungan flavonoid dan polifenol yang terdapat pada buah karonda dimana flavonoid dan fenol termasuk senyawa yang bersifat polar (Harborne et al., 2006). Semua waktu memberikan pengaruh yang berbeda terhadap nilai LC50 dimana waktu 96 jam merupakan waktu yang paling berpotensi terhadap penurunan nilai LC50 diikuti dengan waktu 72, 48 dan 24 jam. Hal ini disebabkan semakin lamanya waktu paparan, daya tahan tubuh ikan zebra semakin menurun (Yang et al., 2018). Hasil perbedaan pengaruh dari nilai ratarata pengujian ekstrak dan fraksi terhadap nilai LC50 terdapat pada Tabel 4.

Tabel 4. Hasil Uji Lanjut Sampel dan Waktu Terhadap LC50

\begin{tabular}{ccccc}
\hline \multirow{2}{*}{ Sampel } & \multicolumn{4}{c}{ Waktu (jam) } \\
& 24 & 48 & 72 & 96 \\
\hline Fraksi n-heksana & 685,576 & 630,133 & 617,184 & 608,261 \\
Fraksi etil asetat & 596,398 & 599,035 & 588,173 & 571,781 \\
Fraksi air & 633,092 & 610,657 & 603,570 & 546,690 \\
Rata-rata & $636,511^{\text {a }}$ & $613,779^{\mathrm{b}}$ & $603,030^{\mathrm{c}}$ & $577,020^{\mathrm{d}}$ \\
\hline
\end{tabular}

Keterangan: angka yang diikuti huruf superskrip yang sama menunjukkan pengaruh yang tidak berbeda nyata

\section{Hasil Uji Toksisitas terhadap Daya tetas Embrio Ikan Zebra}

Pengujian daya tetas embrio harus memenuhi kriteria validasi menurut OECD (2013). Kriteria tersebut diantaranya yaitu kelangsungan hidup keseluruhan embrio pada kontrol negatif harus $\geq 90 \%$ sampai akhir paparan 96 jam dan tingkat penetasan pada kontrol negatif harus $\geq 80 \%$ di akhir paparan 96 jam. Hasil pengamatan kontrol negatif pada ekstrak dan fraksi menunjukkan $100 \%$ menetas dengan baik, karena tidak adanya senyawa aktif yang dapat menghambat kerja enzim chorionase sehingga proses pemecahan cangkang berjalan dengan baik (Gusrina, 2014). Hasil ini menunjukkan bahwa pengujian pada ekstrak dan fraksi dikatakan valid.
Hasil pengujian pada ekstrak dan fraksi menunjukkan adanya penurunan persentase daya tetas dari setiap waktunya. Hal ini disebabkan senyawa aktif yang terkandung dalam buah karonda diduga dapat menembus chorion yang bersifat menghambat pertumbuhan dan perkembangan embrio serta dapat menyebabkan kematian pada embrio (OECD, 2013). Pemaparan bahan uji pada konsentrasi $750 \quad \mu \mathrm{g} / \mathrm{mL}$ menyebabkan penurunan persentase penetasan embrio ikan zebra yang signifikan, karena semua embrio mengalami hipertonik dimana sel embrio mengkerut sehingga berhenti berkembang terutama pada waktu pemaparan 96 jam (Pratiwi, 2004). Hasil uji daya tetas dari ekstrak dan fraksi buah karonda terdapat pada Tabel 5. 
Tabel 5. Hasil Uji Daya Tetas Ekstrak dan Fraksi Buah Karonda

\begin{tabular}{cccccccc}
\hline \multirow{2}{*}{ Sampel } & \multicolumn{7}{c}{ Daya tetas (\%) } \\
\cline { 2 - 8 } & $\begin{array}{c}\text { Waktu } \\
\text { (jam) }\end{array}$ & KN & P1 & P2 & P3 & P4 & P5 \\
\hline \multirow{5}{*}{ Fraksi n-heksana } & 24 & 3,33 & 0 & 0 & 0 & 0 & 0 \\
& 48 & 100 & 86,67 & 80 & 53,33 & 40 & 0 \\
& 72 & 100 & 80 & 70 & 46,67 & 33,33 & 0 \\
Fraksi etil asetat & 96 & 100 & 80 & 70 & 40 & 26,67 & 0 \\
& 24 & 0 & 0 & 0 & 0 & 0 & 0 \\
& 48 & 100 & 63,33 & 56,67 & 26,67 & 20 & 0 \\
Fraksi air & 72 & 100 & 56,67 & 50 & 20 & 13,33 & 0 \\
& 96 & 100 & 53,33 & 46,67 & 16,67 & 10 & 0 \\
& 24 & 0 & 0 & 0 & 0 & 0 & 0 \\
& 48 & 100 & 66,67 & 60 & 43,33 & 33,33 & 0 \\
& 72 & 100 & 56,67 & 40 & 33,33 & 20 & 0 \\
& 96 & 100 & 53,33 & 36,67 & 16,67 & 10 & 0 \\
\hline
\end{tabular}

\section{Hasil Uji Toksisitas terhadap} Malformasi Organ Embrio Ikan Zebra

Hewan coba yang digunakan dalam pengujian ini adalah embrio ikan zebra yang berusia 8 jam karena pada tahap ini belum terbentuk organ sehingga dapat membantu dalam pengamatan malformasinya. Alasan digunakannya embrio ikan zebra karena proses pembiakan yang cepat (Rubinstein, 2006). Selain itu embrio ini transparan sehingga mudah untuk diamati pertumbuhan dan perkembangan organnya dan embrio ini memiliki kesamaan gen dengan gen manusia juga (Van den Bulck et al., 2011).

\section{Morfologi Embrio Ikan Zebra pada Usia 96 Hpf}

Hasil morfologi embrio zebrafish pada usia 24. 48, dan 72 dan 96 jam. Pada usia 96 jam terlihat kelainan pada tulang ekor, yolksac dan pericardium (Gambar 1). 

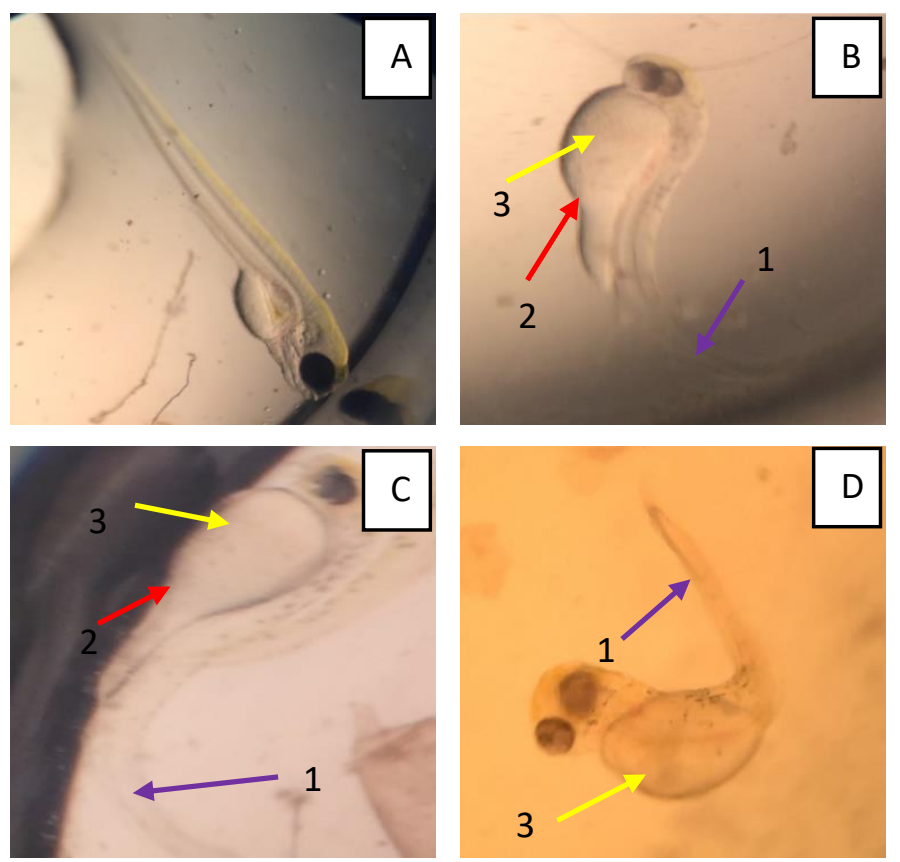

Gambar 1. Morfologi embrio zebrafish setelah 96 jam

Keterangan: embrio dengan pertumbuhan yang normal (A), kelainan pada tulang ekor (B), edema yolk sac (C) dan edema pericardium (D). (1) tail, (2) yolksac, (3) edema pericardium

\section{SIMPULAN DAN SARAN Simpulan}

Toksisitas dengan nilai LC50 untuk fraksi n-heksana, fraksi etil asetat dan fraksi air adalah $608,261 \mu \mathrm{g} / \mathrm{mL}$, $571,781 \mu \mathrm{g} / \mathrm{mL}$ dan 546,690 $\mu \mathrm{g} / \mathrm{mL}$. Ekstrak air buah karonda paling toksik dibandingkan ketiga fraksi dan pengamatan selama usia $96 \mathrm{hpf}$ mengalami perubahan pada tulang ekor, edema yolk sac dan pericardium. Kategori ketoksikan bahan uji termasuk kategori tidak toksik. Saran perlu dilakukan uji aktivitas antiinflamasi sebagai lanjutan dari uji toksisitas akut untuk mendapat data awal dari penelitian aktivitas.

\section{DAFTAR PUSTAKA}

Anupama, N., Madhumitha, G. \& Rajesh, K. S. 2014. Role of dried fruits of Carissa carandas as antiinflammatory agents and the analysis of phytochemical constituents by
GC-MS. BioMed Research International, Special Issue.

Azeez, S., Karunakaran, G., Tripathi, P. C., Shivashankara, K. S., \& Roy, T. K. 2016. Evaluation of antioxidant activity, total phenolics and phytochemical content of selected varieties of karonda fruits (Carissa carandas). Indian Journal of Agricultural Sciences, 86(6): 815822.

Depkes RI. 1992. Pedoman Fitofarmaka Dalam Keputusan Menteri Kesehatan Republik Indonesia Nomor 761/Menkes/SK/IX/1992. Departemen Kesehatan Republik Indonesia. Jakarta.

Dhodi, J. B., Thanekar, D. R., Mestry, S. N. \& Juvekar, A. R. 2015. Carissa carandas Linn. fruit extract ameliorates gentamicin-induced nephrotoxicity in rats via attenuation of oxidative stress. Journal of Acute Disease, 4(2): 135-140. 
El-Sayed Ali, T. \& Legler, J. 2011. Developmental toxicity of nonylphenol in zebrafish (Danio rerio) embryos. Indian Journal of Marine Sciences, 40(4): 509-515.

Gad, S. C. 2014. LD50/LC50 (Lethal Dosage 50/Lethal Concentration 50) in Encyclopedia of Toxicology Third Ed, Editor: Wexler, P. Academic Press. USA.

Gusrina, G. 2014. Genetika dan Reproduksi Ikan. Deepublish.

Hanani, E. 2015. Analisis Fitokimia. Penerbit Buku Kedokteran EGC. Jakarta.

Harborne, J. B., Padmawinata, K. \& Soediro, I. 2006. Metode Fitokimia Penuntun Cara Modern Menganalisis Tumbuhan. ITB

Huang, D., Li, H., He, Q., Yuan, W., Chen, Z. \& Yang, H. 2018. Developmental toxicity of diethylnitrosamine in zebrafish Embryos/juveniles related to excessive oxidative stress. Water, Air, and Soil Pollution, 229(3): 81.

Kemenkes RI. 2011. Suplemen II Farmakope Herbal Indonesia. Departemen Kesehatan Republik Indonesia.

Mishra, C., Sasmal, D. \& Kumar, D. 2017. In vitro antioxidant activity of chloroform and ethanolic fruit and root extracts of Carissa carandas Linn. J.Bio.Innov, 6(5): 741-748.

OECD (Organisation for Economic Cooperation and Development). 2012. OECD guideline for testing of chemicals: fish, acute toxicity test.

Parasuraman, S. 2011. Toxicological screening. Journal of Pharmacology \& Pharmacotherapeutics, 2(2): 7479.

Rohmah, J., Rini, C. S. \& Wulandari, F. E. 2019. Aktivitas sitotoksik ekstrak selada merah (Lactuca Sativa var. crispa) pada berbagai pelarut ekstraksi. Jurnal Kimia Riset, 4(1): 18-32.

Rubinstein, A. L. 2006. Zebrafish assays for drug toxicity screening. Expert Opinion on Drug Metabolism and Toxicology, 2(2): 231-240.

Sudjaroen, Y. \& Suwannahong, K. 2017. In vitro antioxidant, antibacterial, and cytotoxicity activities from Karanda (Carissa carandas L.) fruit extracts. International Journal of Green Pharmacy, 11(1): 189-193.

Van den Bulck, K., Hill, A., Mesens, N., Diekman, H., De Schaepdrijver, L. \& Lammens, L. 2011. Zebrafish developmental toxicity assay: A fishy solution to reproductive toxicity screening, or just a red herring?. Reproductive Toxicology, 32(2): 213-219.

Virmani, R., Virmani, T., Sorout, G. \& Gupta, J. 2017. Buccal drug delivery system- approach to improve the bioavailability. Research in Pharmacy and Health Sciences, 3(2): 294-302.

Waynon, W. J. \& Finley, M. F. 1980. Handbook of Acute Toxicity of Chemicals to Fish and Aquatic Invertebrates. United States Department of the Interior Fish and Wildlife Service, Resources Publication. USA.

Yang, J., Li, W., Liu, Y., Wang, Q., Cheng, X. \& Wei, F. 2018. Acute toxicity screening of different extractions, components and constituents of Polygonum multiflorum Thunb. on zebra fish (Danio rerio) embryos in vivo. Biomedicine and Pharmacotherapy. 99(1): 205- 213. 